\title{
X-morphising: review essay of Bruno Latour's Aramis, or the Love of Technology ${ }^{\dagger}$
}

\author{
E Laurier, C Philo \\ Department of Geography and Topographic Science, University of Glasgow, Glasgow G12 8QQ, \\ Scotland; e-mail: elaurier@geog.gla.ac.uk; cphilo@geog.gla.ac.uk \\ Received 16 July 1998; in revised form 10 December 1998
}

\begin{abstract}
An extended review is presented of Bruno Latour's book Aramis, or the Love of Technology (Harvard University Press, 1996). Attention is paid to the textual style and strategies in the book, and also to how it fits in with, and exemplifies, many of the more abstract claims central to Latour's actornetwork theory. In particular, consideration is given to the provocative arguments in the book about the status of nonhuman beings in social-scientific research, and to the specific manoeuvre whereby Aramis, this transportation project which never quite made it from being an idea to being a completed object, is accorded agency - and even a voice - in the text. The ' $x$-morphising' which underpins Aramis in this respect is examined, and is subsequently criticised for a flattening out of agency which permits humans and nonhumans to be regarded as 'social' equivalents. Although attracted to Latour's radical emancipation of nonhuman things from a social-scientific netherworld, we nonetheless conclude by worrying about the flat and undifferentiated 'spatial imaginary' at the heart of what he is attempting to do for actors of all kinds in Aramis.
\end{abstract}

\section{Aramis, or the love of a book on technology}

"'But I thought we had to take everything into account...'

'Few things are coming together, on the contrary; they're rare and fragile filaments, not big bubbles to be tied together by big arrows. Their extensions are unpredictable, it's true; their lengths as well. And they're very heterogeneous. Maybe we'll go to South Korea after all, or we'll go to see Reagan, but simply because the Aramis maze will oblige us to draw a picture of that corridor of its labyrinth, and because an Ariadne has slipped her thread into it, not because we have to take into account the international element, or the technological infrastructure.'

He even obliged me to observe for myself that the violent blow he struck with his fist on his desk had no visible influence on the chapter of Aristotle's Metaphysics that was filed under the letter A at the top of his bookshelf.

'You see: not everything comes together, not everything is connected.'

After that interesting physics demonstration, he harangued me again about the notion of networks. They were all fanatical about networks in that shop."

$$
\text { Latour (1996, pages } 152-153)^{(1)}
$$

Sometimes you read a book which offers so many solutions to so many problems that you immediately want to reshape your research around it. Aramis, or the Love of Technology is one of those books for us. It is nominally "a single case study in scientification" (page vii), yet it addresses in an almost populist manner numerous enduring questions about what social scientists can offer to engineers, planners, developers, and users of technology. In particular, these are questions about how to understand nonhuman beings, most

$\dagger$ Aramis, or the Love of Technology by B Latour, translated by C Porter; Harvard University Press, Cambridge, MA, 1996, 336 pages, $\$ 45.00$ cloth, $\$ 19.95$ paper (UK: $£ 28.50$, £13.50) ISBN 0-67404322-7, 0-674-04323-5

(1) All of the undated quotes in the text-for example (page 199) - refer to the book under review (Latour, 1996). Where we write Aramis, in italics, we are referring to the book; where we write Aramis, in plain, we are referring to the technological project of this name. 
notably machines. They also include questions about both the character of research projects and the fabrication of artefacts, as well as questions about the textual representation of science and technology.

Aramis draws upon the wonderfully productive spatial imaginary of 'networks', demonstrating the complexities created when we think about connections and relations rather than about discrete subjects and objects. It is a book which offers a passage between the dualistic approaches which still lead many human geographers and other social scientists into pursuing either subjective or objective knowledges. ${ }^{(2)}$ For us, Aramis is a beautifully impure book (Law, 1994) about how the things which we routinely try to hold apart, such as political parties and railway carriage couplings, are in practice inextricably linked to one another. As the opening quote indicates, these things are always bound into specific networks made out of 'filaments' (Hinchliffe, 1999), multiple threads of reality that are always individually fragile. Not everything is connected to everything else, however, for the slap on a desk may cause a book to fall off a nearby shelf but generally the slap remains unconnected to the books. In the making of networks a multitude of actors, human and nonhuman, are enlisted into action (or inaction, as in a bookshelf keeping the books off the desk). ${ }^{(3)}$ In connecting together all kinds of things, what we then have are 'hybrids' formed from the mixing up of subjects and objects, humans and nonhumans. Agency is achieved for "speaking subjects" (page viii) and "poor objects" (page viii) as they are strung along, so that people are extended into and through objects, while equally objects are extended into and through people to (per)form networks. Aramis duly raises up the (nonhuman) 'poor objects' of the world for our (human) 'attention and respect' as coequal 'social' agents, and as always involved, if too often subordinated, in our own projects.

Bruno Latour, the author of Aramis, is one of the leading figures in social studies of science, knowledge, and technology, ${ }^{(4)}$ and is closely allied, alongside others, with the development of 'actor-network theory' (ANT) (Callon and Latour, 1981). However, like many poststructural thinkers, Latour is unwilling to associate himself with a theoretical metadiscourse. He has not gone so far as to disown ANT as it spreads and mutates, and, given Derrida's failure to disown 'deconstruction' as this has similarly spread and mutated, we can perhaps understand why. What Latour claims to be doing against 'big' theorising is instead telling stories and providing weak explanations: "it [Latour's approach] adds its own interpretations to those of the actors whose fate it shares, often less felicitously than they.... Without any knowledge other than what it gets from them [those under study], it is free at least from the crushing responsibility of being more scientific than the actors" (page 200). All that Latour claims to be seeking is a degree of stability in his interpretations, which can be found in the recurrent terms such as 'stability, translation, interests' and the like that 'perform the reality' of his stories.

(2) There is now a rich vein of scholarship within human geography, for instance, which is striving to deploy Latourian-inspired ideas in overcoming this dualism (and a number of others): for example, Bingham (1996), Demerrit (1996), Hinchliffe (1996; 1999), Murdoch (1995; 1997a; 1997b), Thornes (1998), Thrift (1996), Whatmore (1997), Whatmore and Thornes (1998).

(3) We will use the term 'actor' throughout the article, even though Latour sometimes uses the term 'actant' (see also Haraway, 1991) to signal a definition of the term that does not rule out nonhumans as valid (social) agents comparable with humans. We will hold on to the term actor because, like that of 'self', it has a certain tie with human beings which we do not wish to be shifted out of focus and therefore out of contention, especially when such a radical redefinition of social agency is being put forward. Arguably, the very use of the term 'actant' enables the sleightof-hand manoeuvre for which we criticise Latour subsequently in the paper.

(4) We will use the acronyms SSK for the 'sociology of scientific knowledge' and STS for 'sociotechnical studies', although we are wary of both the 'technical' style that this brings to our writing and the degree of opaqueness that such acronyms create for a more general readership. 
His trajectory through the field of knowledge production has, like that followed by many of his contemporaries, shifted from scientific to technological practices and knowledges (Woolgar, 1991). He has followed, in his terms, a chain of 'translations' from scientists at work inside the laboratory making science to engineers at work outside the laboratory making technology. His latest work, Aramis, refer obliquely to the reasons for becoming interested in technological projects:

"As accustomed as we have become to the idea of a science that 'constructs', 'fashions' or 'produces' its objects, the fact still remains that, after all the controversies, the sciences seem to have discovered a world that came into being without men [sic] and without sciences" (page 23).

Shifting to the study of technologies "gives greater freedom to the observer of machines than to the observer of facts" (page 24), because machines, unlike facts, do not appear to have existed before they were fabricated. This is a significant claim, and one to which we will return. Latour then argues that engineers are like novelists, because they invent things, situations and characters that do not yet exist, that are fictions, except with the one critical difference that these fictions may one day shift off the page and gain reality. With this similarity and possibility in mind, Latour has written something very close to a sociological fiction about a public transportation project that nearly "transformed into an object", but which instead, "[i]n the archives, ... turn[ed] back into a text, a technological fiction" (page 24). Part of the charm of Aramis is that Latour is also like a novelist, and has devoted his considerable writing skills to producing an important theoretical work which is also a remarkable example of how to document a case study, while simultaneously being a page-turning murder mystery. And the corpse that sets off the whole investigation is the technological project called Aramis.

\section{The assembled anatomy of an actor-network text}

The technology around which this book unfolds is Aramis, an experimental design and subsequent research initiative for an innovative rapid personal transit (RPT) system intended to service densely populated urban centres. This was a French design based on the idea of separate 'cars' for individual or small numbers of people which, although running on rails or a track, would move independently to collect passengers from small stations and to transport them to their stated destination stations. Aramis was hence to be a hybrid creation, combining the independence of an automobile and the transport efficiency of a regular railway train. Like automobiles on the road, Aramis would never be mechanically coupled together to form lengthy trains, even if from a distance the Aramis cars or carriages travelling in convoy might resemble a standard train (see figure 1). Numerous technological 'advances' were involved, notably those of 'nonmaterial couplings' (intercar linkages orchestrated electronically, optically, and acoustically), variable reluctance motors, computerised on-board control units, and a new form of track layout at stations. The overall research project went through several prototype stages, but was eventually scrapped, whereas related public transportation schemes seeking to be equally flexible did later come into existence.

Latour's account of this story could be regarded as a brilliantly written case study of interest only to transport geographers, town planners, and other groups involved in public transportation systems. Yet its reach is far wider, and for many readers the main draw will be more conceptual, given that Aramis opens a quite particular window on the changing character of Latour's thinking in the aftermath of his respecfication of science, society, and modernity in We Have Never Been Modern (Latour, 1993a). His dramatic claims there about rewriting the 'modern constitution' which holds apart culture and nature, the human and the nonhuman, implied a form of investigation 


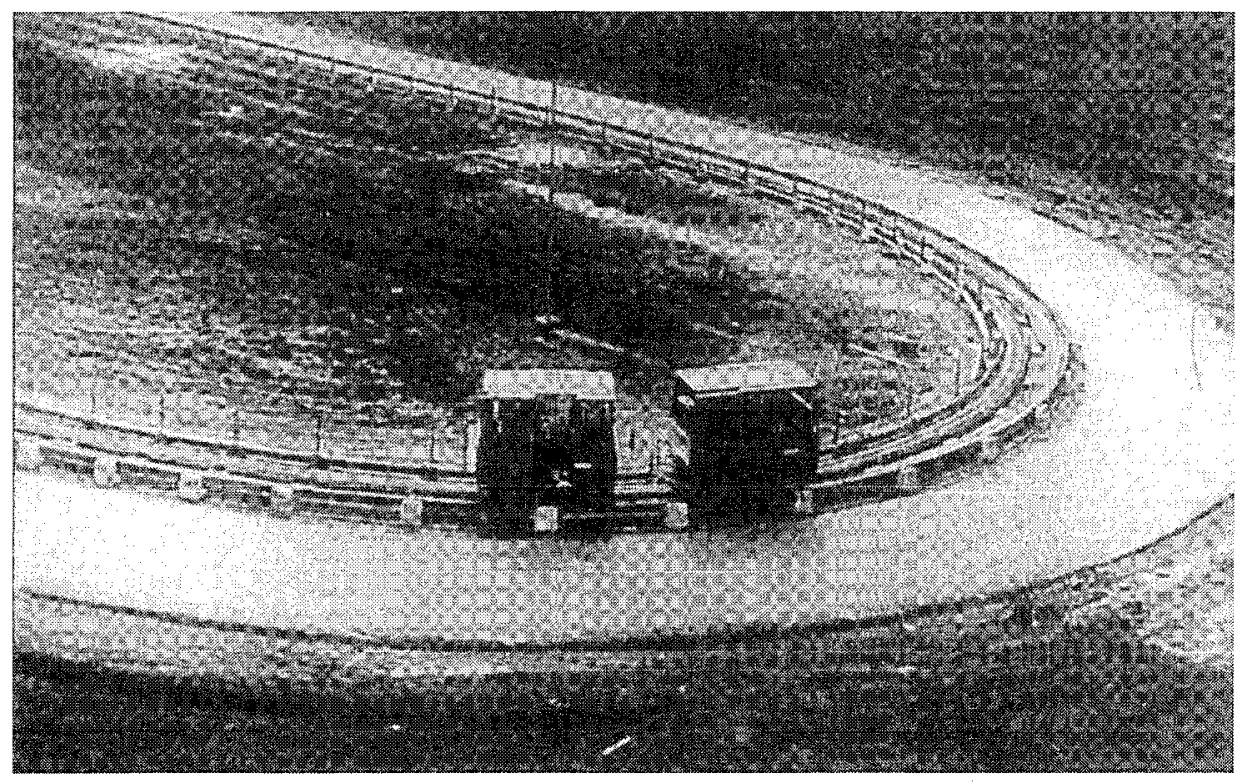

Figure 1. Aramis at the prototype stage (source: Latour, 1996, photograph 3, between pages 158 and 159). Latour's caption to this photograph: "In 1973, in a beet field near the Orly Airport runways, the first cars of the first Aramis prototype were tested. This photo shows the test track, along with two little cars that are running quite close to each other, even though they are not mechanically coupled."

that would explicate more than just the peculiar associative powers of scientists and laboratories (Latour, 1987; Latour and Woolgar, 1979). In this sense, Aramis entails an empirical 'follow-up' to We Have Never Been Modern, an attempt to register the noisily animated 'parliament of things' jostling together in our never-been-modern world, and in its extension away from 'science' it can legitimately be read against the broader landscape of debates around the rapid spread of ANT into the social sciences. To an extent this is our objective, and there are moments in what follows where we read sideways from Aramis (as book) to cross over critically into ANT (as project). There is no easy equation between Aramis and ANT, however, and we recognise that how actor-networks are excavated and inspected in this book is necessarily specific (and why this should be so we will return to later). Our reading produces a glance at ANT, and no more, with ANT being noticed, as it were, through the lens provided by Aramis. Perhaps now we have already dwelt on ANT too long already for some readers, but we hope not because we believe that Aramis is a book that could appeal to those who might normally give ANT and its difficulties a wide berth. The usual reviewer's conceit is to offer to make a demanding book more accessible, but in this case we simply wish to make an already accessible book even more accessible, partly by freeing it from the demands of an audience who only wish to read it through ANT lenses. So let us now begin with an account of how the book itself has been assembled through the exceptional craft of Latour.

In outline, Aramis is a 'novelistic' report on a multisite ethnographic study of a failed technological project, deploying a rich archive of documentary sources (planning and policy papers, publicity materials, consultancy reports, memos, scribbled notes), iconographic sources (photographs, maps, diagrams) and also in-depth interviews with many of the relevant human actors. There are many different styles of writing which appear in the text, always related to the different materials being reported, and these 
different styles are commonly 'framed' by different typefaces (Times, Futura, Chicago) and formatting (justified, unjustified, preceded by thick section breaks, archive labelled). The hinge of the book is a novelistic 'rites of philosophy' tale of a young, slightly naive engineering student taking a sandwich-year course with an older sociology professor called Norbert (arguably a stand-in for Latour himself). The reader is led to regard Norbert as the author of the many third-person 'academic' (and occasionally footnoted and referenced) theoretical passages wherein his (and on the basis of his past writings, Latour's) 'superrefined sociology' of technological projects is laid out authoritatively, and then sometimes revised. The young engineer, meanwhile, offers ironic and even comic first-person reflections on the period of his research. He comments on Norbert and his sociology, recounting his 'wise old inspector and rookie cop' conversations with Norbert, and often whispering his favoured engineering-based explanations for why Aramis fails. ${ }^{(5)}$ It is also through the student's words that the crowded streets and inadequate transport facilities of Paris come into view, acting as a foil for claims about the genuine need for something like Aramis. Supporting this material there are many evidentiary citations from 'real-interviews' and 'genuine documents' as collected by Latour (see page $\mathrm{x}$ ), and here they are microscopically scrutinised by Norbert and his student. There is also in the text a disassembled biography of 'someone nonhuman', italicised sections of text where Aramis is allowed to speak for and about its almost coming into being, and about its death. As Latour explains, "[m]ysterious voices ... chime in and, drawing from time to time on the privileges of prosopopoeia, allow Aramis to speak" (page $\mathrm{x}$ ). This strategy is obviously unusual and controversial, but it clearly follows from the broader impetus of Latour's thinking which increasingly wishes to incorporate nonhuman things at the heart of social-scientific inquiry.

Aramis is fascinating for this remarkably hybrid style of writing. It is indeed a 'polyphonic' book (Crang, 1992) in its switches between diagrams, maps, lengthy excerpts from technical, governmental, industrial, and newspaper reports, and in mixing up transcripts with exegeses, fictionalised dialogues with the imagined voices of Aramis and its associated nonhuman actors. What is perhaps most surprising, though, is that the result is still a readerly rather than a writerly text (Barthes, 1982). In other words, a large part of the labour of assembling the text is not left to the reader. As those who have read other academic experiments with the form of writing will know, these can often be frustrating, difficult, and ultimately seem rather pointless (for example, Pfohl, 1992). Latour's book, alternatively, reminds us that it can be enjoyable and stimulating, and ultimately reinforce the wider arguments which the author is advancing. What makes Aramis particularly enjoyable is that, among other qualities, it is well plotted-disparate events and actors are shown to be connected by the denouement-as well as frequently being amusing when reporting the humour of interviewees and the mocking tactics of both the sceptical engineer and the know-it-all professor. It also shifts quickly between its materials so that the reader is never mired in overlong empirical sections or overly dense theory-building. As to how it reinforces its arguments by its form, one example is Latour's claim that "no technological project is technological first and foremost" (page 32), and that 'heterogeneous engineering' is required in such a project. Heterogeneous engineering is the blending together of social and technological issues into a hybrid which is able to gather into one project what seem to be purely social problems, on the one side, and what seem to be purely

(5) Straightforward explanations couched in terms of cost, dodgy politics, and technical failure are the standard fare of much work in the field of STS, and to some extent Latour is writing against such 'reductionist' accounts (while apparently grudgingly admitting, through the student, that such accounts are maybe not always inappropriate). For a text which restates the 'usualsuspects' position against the likes of Latour, see Gross and Levitt (1994). 
technical problems, on the other. This is the very trick that Aramis as a text carries out: it is a writing-reading machine which interchanges technical reports with problems from social, cultural, economic, and political theory.

Beyond such experimentation, the book also has many of the attributes of a reflexive text: it comments on its textuality and renders visible the processes by which it is fabricated. Latour has long been interested in the discursive nature of truth claims made by scientists, and yet his reflexivity seems to differ from that displayed by other members of the 'network shop' by its very openness. Other reflexive texts (Ashmore, 1989; Woolgar, 1988) striving to show the frame which fixes their meanings often end up being curiously closed-off affairs. In claiming to fore-see what can be made of them by others, their own self-referentiality seems to banish unsolicited outside reinterpretations. They often contain a metacommentary on the question of exactly how they work, and usually also a critique of how a subordinate (and naive) nonreflexive text works (for example, a business report, a statistical survey, another sociology article). The selfcommentaries effected by such texts do recur to an extent in Aramis, but we would suggest that the latter manages to remain less knowing, precisely by virtue of not being wholly absorbed in its own written constitution. Indeed, despite Latour's (1988) earlier objections, Aramis retains an affinity with ethnomethodological treatises because it comments not only on the process of writing, but also on the very processes of researching (as undertaken by Norbert and his student, but also as undertaken by engineers on the Aramis project). The narrative drive of Aramis duly reconstructs the open-ended qualities of gathering accounts and reports, constantly shifting sideways rather than upwards toward the 'view from nowhere', and in so doing it constantly engages with new, changing, and indelibly situated interpretations concerning the fate of Aramis which emerge 'from the field'.(6) By the end of the book, the professor and his pupil do not have a 'total history' or a 'metahistory' of Aramis, but instead little more than a long list of different understandings of Aramis summarised from those involved in the building of this train-that-never-was. The long list of different understandings of Aramis then comprises part of Latour's solution to his central research question - who killed Aramis or why did Aramis fail to gain reality?-which is that there were far too few compromises made in the fashioning of Aramis. The list of frequently divergent understandings was never short enough to be achievable or agreeable for the many actors involved.

Yet the openness of Aramis is only partial, and in his listing of the actors' explanations, Latour becomes like an expert lawyer rehearsing his clients and ensuring that the empirical 'evidence' all supports his final version of events. And seen in this light, we can detect another double-coding within the book whereby Latour plays upon the notion that he really is investigating a murder: the murder of an actor-network known as Aramis. Just as the wise old investigators and their naive assistants work through numerous possibilities and feasible murderers before solving the 'case' by its close, so Latour pursues this kind of narrative logic in his (or Norbert's) investigation of Aramis. Another paper by him on Aramis is actually entitled "An ethnography of a high tech case" (Latour, 1993b); at several points in Aramis Latour mentions the American sleuth 'Columbo'; and at the close of the book he even invokes Eco's solution to the intellectual murder mystery The Name of the Rose (1988) when declaring that "we've found the hidden staircase" (page 212). It is true that one of the stated ambitions

(6) This is not the place to discuss arguments about the problems with the decentred 'view from nowhere' (the 'God trick') which characterises many academic works of many different hues, nor to debate alternative proposals which insist on recognising the unavoidably 'partial' and 'situated' cast of all knowledges (even those claiming a more universal provenance). A key paper in this respect, emerging from feminist inquiry, is by Haraway (1988; see also Rose, 1997). 
of the book is to exemplify a hybrid literary genre called "scientifiction" (page ix) comprised from the discursive logics of both fiction and science without being a pure case of either one, and that he wants his text to "undo the deleterious effects upon its readers of being believed too little [fiction] nor believed in too much [science]" (page 166; see also Latour, 1988). ${ }^{(7)}$ Even so, we might want to question whether Latour has, in the self-consciously modest tone of his book, ended up creating a theory of sociotechnical action so convincing as 'legal case' (rather than case study) because so well crafted in its citations, intertextual neatness, and argument that it is hard to interpret the evidence in any fashion other than his own. ${ }^{(8)}$

\section{Symmetrical projects: Aramis and Latour's superrefined sociology}

Running from 1969 to 1987, Aramis went through four development phases of increasing scale and cost in which a number of 'successes' in engineering brought this particular experiment in RPT very close to gaining full reality. In 1987 Aramis was surprisingly 'terminated', and its surviving human and nonhuman actors were put to work elsewhere. Aramis thus became what an unwitting observer of events might call a gigantic waste of public resources, and, in its incompletion, a costly failure. Yet Latour questions the very terms 'success' and 'failure' as a basis for examining why a technological project becomes a technological object, why a collection of 'signs, language, and texts' becomes a taken-for-granted train system that carries people to work in the morning. As he painstakingly documents, for Aramis, as for most machines, there are many steps between the beginning of a technological project and its appearance as an apparently complete object. There is seldom a fatal flaw inherent in either the originating design or the basic machinery, and such an inevitably retrospective view of things - supposing that success or failure can only be judged post hoc-hides all of the work of the engineers along the way, and ignores too the multiple connections to other actors (human and nonhuman) upon which any machine relies. At the close of the book, Latour actually lays the blame for the death of Aramis on the belief in the existence of 'complete objects'. It was such a belief that prevented Aramis from holding together "passions, transported people, money, Communist ministers and software" (page 213), because, when Aramis was treated as a complete and finished object, it could not transform itself "to hold on to its environment, and ... gain in existence" (page 212). This belief in complete and completed objects also led to Aramis being labelled a failure, even though many of its disassembled actors went on to success in networks elsewhere: an entire public transport system based on a pared-down Aramis (called VAL) was built

(7) Although Latour (1993a) makes a strong argument that 'we have never been modern', we would still find ourselves describing his writing style in Aramis as 'modernist': consider his propensities for both Mary Shelley and 18th-century philosophers, his charting of the multiple perspectives of and from his characters, his concern with technology alongside the human (and of course nonhuman) condition, and of course his irony. In some respects, though, Aramis shares many of the attributes of post-modern novels in its use of pastiche, dense intertextuality, and the flattening out of history.

${ }^{(8)}$ Latour sometimes uses the term 'fraternal' as a substitute for modest, because he is also wary of those Machiavellian rhetorics of modesty in the social sciences which serve to disguise acts of interpretative or explanatory war. Under the rubric of fraternality, there are also some gender and other hierarchical components to Latour's research activity that might bear closer examination, especially as he never seems to have any trouble accessing powerful actornetworks (personal communication, G Davies, 1998). Anyone who has researched such elites will realise that his has been an unusually easy path through the labyrinth, but no disruptive reflections on any such difficulties of actually doing the research, of being an inferiorised rescarcher 'in the field', are allowed to trouble the smooth flow of the story through the turning pages of the book. 
in Lille, and more such systems are planned; the motors developed for Aramis are being used productively and profitably in other machines; the engineers trained on Aramis have gone on to do valuable work in other places.

This willingness to disassemble both successes and failures forces us to recognise that all technological phenomena which endure in the world are built up of myriad transactions and unities between different orders of 'reality' (human and nonhuman, scientific and artistic, large and small, compact and stretched). Latour's additional argument about those technologies which do struggle beyond prototypes, and which avoid turning back into papers stored in filing cabinets, are that they entail technologies whose human advocates (the scientists, the engineers, the planners, the politicians, the bureaucrats) genuinely 'love' them: who nourish them with care, affection, and attention, who never lose sight of what they are supposed to be, who are always committed to their cause, and who do not take 'no' for an answer. The results are therefore even more messily hybrid, entailing chunks of machinery and electronics shot through with the loves, hopes, desires of their human cohabitees. In the absence of such love, the technologies remain as ideas, as possibilities batted backwards and forwards by different groups of not-overly-interested human actors, as countless scenarios in which no human actor is sufficiently interested to sift the inspired from the half-baked. This was the fate which sadly befell Aramis, and there is a sense in the book of sadness, of mourning for the lost entity: Latour is sad, as too are Norbert and his student, particularly when stuck in the clogged-up traffic or metro of Paris. Aramis itself, though, is both sad and angry.

It is important to appreciate the work that Aramis does for Latour, in that he clearly uses the book as a vehicle to demonstrate the utility of many concepts developed previously (Latour, 1987; 1988; 1991; 1992; 1993a) concerning SSK and STS. Key Latourian notions such as translation are made concrete in relation to Aramis (for example, pages $32-34$, pages $118-120$ ), as too are notions of size, scale, and reach as 'accomplishments' not pregiven dimensions (for example, pages 44-46, pages 108-109, pages 126-127), of the enlisting (or 'recruiting' or 'involvement') of all manner of agents (ideas, materials, objects, personnel) in the 'making' of projects (for example, pages 56-58), and of the protection of projects by all manner of 'allies' great and small (for example, pages $71-72$ ). Also there is a sustained critique of standard 'contextual' accounts for the success or failure of scientific and technological projects, ones which fix their explanations in the prevailing economic or political context where a project is set (for example, the financial constraints, the party-political wranglings). Indeed, Latour offers a convincing critique of 'big explanations' which invoke such contexts in their architecture, suggesting that they end up doing everything and nothing because they are too inspecific. Instead, he proposes the detailed attention to networks:

"A technological project is not in a context; it gives itself a context, or sometimes does not give itself one.

What is required is ... to study the way the project is contextualised or decontextualised. To do that, the rigid, stuffy word 'context' has to be replaced by the supple, friendly word 'network'. The big explanations in terms of politics, economics, organisation, and technology always turn up, without fail: 'It's politically unacceptable'. 'It isn't profitable'. 'Society isn't ready for it'. 'It's inefficient'. These explanations are always used precisely because they can't be worn out. They're not designed to explain - if that were the case, they would have to wear out in contact with the hard, contorted circumstances....

[T]hese big explanations have to be replaced by little networks" (pages 133-134). 
And again:

"Transforming the context into a certain number of people who represent interests and who all want to achieve the goals of those who they represent does not suffice to enable one to decide whether or not they will have any impact on Aramis, still less to calculate in advance what the impact will be.... Hence the idiocy of the notion of 'pre-established context'. The people are missing; the work of contextualisation is missing. The context is not the spirit of the times which penetrates all things equally. Every context is comprised of individuals who do or do not decide to connect the fate of a project with the fate of the small or large ambitions they represent" (page 137).

These observations are telling in their insistence on a degree of necessary specificity, of focusing unwaveringly on those people and other entities which comprise the immediate smaller 'contexts' or 'little networks' for something like Aramis, and which are in a sense enrolled as elements of this context, a context that is therefore always made in process and not pregiven. ${ }^{(9)}$ This radical approach to context removes it as a subtle safety net for many theorists who will often invoke it as a term akin to social order or social structure, positioning it as an ultimate, if ineffable, shared background to identities, texts, and practices. As Norbert quips to his student: "[n]o, indeed, nothing happens by accident but nothing happens by context either" (page 138).

One of the further, and arguably even more energising, ambitions of Latour's longer term work has been to balance the asymmetry in intellectual treatments of humans and nonhumans. A concern with symmetrical explanations which provide no a priori distinctions between true and false claims in the natural sciences is a longstanding one in STS and SSK (Bloor, 1976). Yet Latour's elaboration of this principle has caused much controversy, and has prompted accusations of a dangerous relativism because it banishes 'society' as the given ground on which social analysts keep their footing (for example, see the debates in Pickering, 1992). The actor-network school after Latour argues that boundaries drawn between nature and society (or between technology and society) obscure the zones where hybrids proliferate, thus creating circular arguments about the strength or weakness of, for instance, social determinism versus natural determinism (Latour, 1993a). Aramis shows why extending the principle of symmetry is important, because it documents the symmetrical acts of blending together mechanical characteristics and social characteristics which are the stuff of the daily problems, resolutions and practices of human (and nonhuman) makers of Aramis. The mixings of people and things, as relevant actors and as part of the context of Aramis, is a task which engineers can be shown routinely to perform: so, while shaping their machines, they shape society. To emphasise, Latour is precisely not arguing for a technological determinism, but rather for attention to the incredibly busy traffic across the supposed great divide between nature, technology, and society (Bingham, 1996). The implication for all social scientists is that, just as writers of SSK and STS have done, we should be willing to look at the social agency of nonhumans: or as we occasionally say, we must seriously heed 'the agency of things'.

(9) It might be added that to some extent Latour's demand here for specificity parallels the demands of geographers that 'contextual thinking' in the social sciences always pay attention to the precise time-spaces which are involved (for example, Gregory, 1994; Hinchliffe, 1996; Thrift, 1996), a degree of precision rarely shown by sociologists, economists, and political scientists. Yet Latour's criticisms also touch on what geographers have done in this respect, arguably demanding a still greater precision about what constitutes a relevant context for a given project (event, movement, etc) and a recognition that such contexts are in effect 'constructed' around/by the project (admittedly out of materials, resources, etc which must be available 'locally' to the project). 


\section{Knocking on the door: someone nonhuman}

Among other moves, We Have Never Been Modern (Latour, 1993a) made a daring argument against not just the strong programme in SSK (see the arguments in Pickering, 1992), but also against what he called the 'modern constitution' of the great divide between the scientific domination of nature and the sociopolitical emancipation of humanity. This is not the place to unpack Latour's complex 're-engineering' of the relationship between the sciences (as representatives of nature) and the social sciences (as representatives of society), but what we can note is how he convinced many readers that we should be extending our definition of social actors beyond humans to the shadowy domain of nonhumans. It has made us personally think very carefully about how to conceptualise agency, action, the human, and the nonhuman. For Chris this has meant considering the agency of animals in shaping human society, and in influencing the character of supposedly 'human' spaces (Philo, 1995; Philo and Wolch, 1998). For Eric this has meant considering the redistribution of competencies, accountability, and repair work between people and things coinvolved in mobile office work and other car-driving related practices of mobility (Laurier, 1996; 1999; Laurie and Philo, 1999). Following the frequent warnings in Latour (1993a), we now look to avoid operating with any great divide between science, technology, and nature, on the one side, and society, on the other, and have striven instead to tease out the proliferation of hybrid subject-objects inbetween.

Central to Latour is this reconceptualising of nonhumans: the 'things' of the world which in conventional works of social science, cultural studies, and human geography are regarded simply as objects, as matter, as mute entities devoid of all human qualities, simply bending to the plans, whims, and desires of human beings (the only actors that count). Latour, for all his self-mockery, is very serious about the constant exchanging and replacing that goes on between humans and things. The development of the cars for Aramis, as an example, involved the substitution of human drivers (a political issue for the driver's union) with several possible assemblages of automated drivers. Yet "in moving from humans to nonhumans, we do not move from social relations to cold technology" (page 62): some of the qualities of human drivers were retained, "like subordination and control, authorisations and orders" (page 62), whereas others were deleted, like hunger for food and the tendency to go on strike. ${ }^{(10)}$ Latour's engineers are duly creating monster-esque characters out of a minimum number of delegated elements of human form and a series of restricted freeedoms. Mary Shelley's Frankenstein has an enduring influence on STS and SSK (Law, 1991), and Latour, in one of his professor - student dialogues, suggests that her search for "dismemberers of assemblages of human and nonhumans" (page 74) provides a rationale for his study of Aramis. Using Frankenstein as the allegorical scientifiction, he examines the meticulous stitching together of the 'interests' and the 'attachments' of humans (electrical engineers, software programmers, company managers, local politicians, and members of government) with those of nonhumans (couplings, railtrack, stations, electric motors) (see figure 2). He studiously avoids claiming that such interests and attachments are exactly the same for any of the actors involved: indeed, the work required of the engineers is to translate and to assemble the different interests of the potentially disloyal actors that they want to involve in building their sociotechnical network.

More provocatively still, the someone nonhuman's biography is frequently written in what appears to be a first-person interior monologue. Aramis hence becomes yet another ' $I$ ' in the book, pondering its own progress from the germ of an idea in a US senate hearing, to another germ in a newspaper report on a world expo, to arguments 


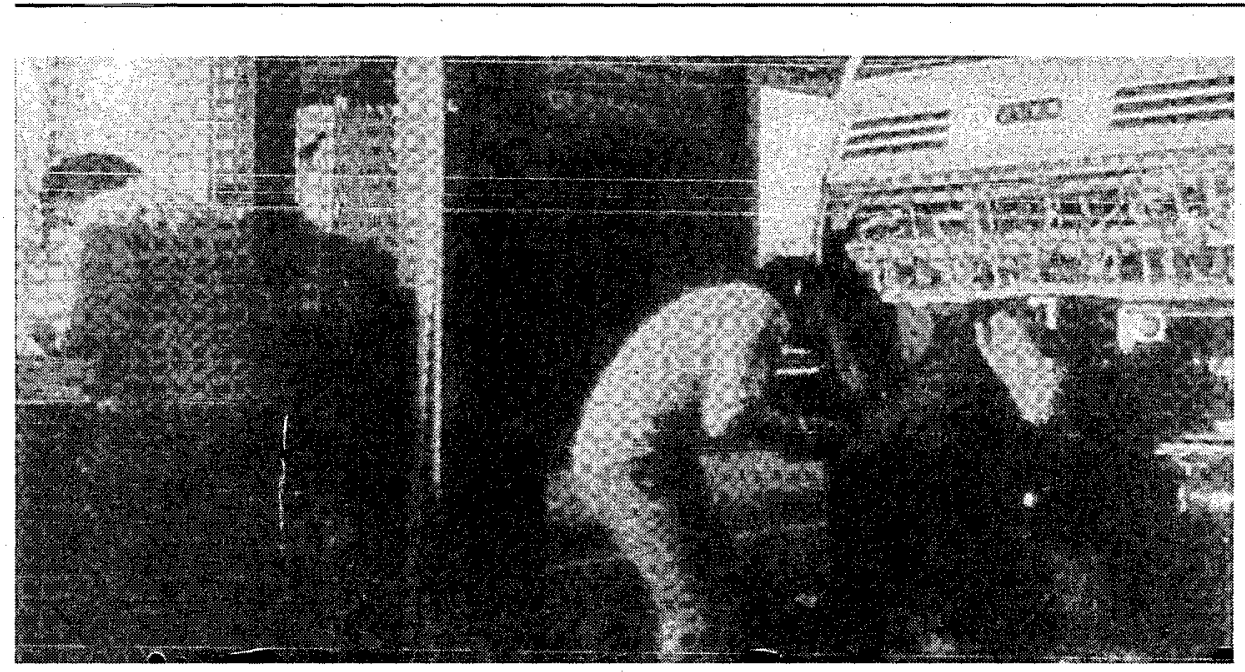

Figure 2. Aramis in the final stages (source: Latour, 1996, photograph 17, between pages 158 and 159). Latour's caption to this photograph: "Aramis in its frantic last days. Technicians surround its carcass, trying to debug its programme and make it work automatically — that is, without their constant intervention. Depending on their success, the car will be swarming inside with bits of information or outside with technicians."

amongst its various bits and pieces (the motor, the chip, the chassis), ${ }^{(1)}$ to discussions between it, God, and Jesus on the subject of creation, to debating its likeness to Victor Frankenstein, and finally to its impassioned j'accuse speech over its untimely death. This textual strategy is something that most social scientists would be wary of doing for any of their 'human' research subjects, perhaps precisely because these subjects can normally speak for themselves. Speaking for things in their first persons arguably makes a mockery of being politically sensitive when representing human subjects either in their own voices or through a cautious third-person citation. Or does it? Earlier work by Latour (1987) on the struggles of scientists to record messages from nonspeaking things by the creation of instruments for detecting signals, examples being X-ray machines, oscilloscopes, and Geiger counters, suggests a way of inscribing messages from things for human interpretation. But such 'observation' is far from the kind of 'inscription' that Latour carries out for Aramis. Would it have been preferable to have included software printouts, electrical motor performance indicators, costings, and safety tests as the messages which were recorded from Aramis by the engineers, and presumably then read by Norbert and his student?

Latour recognises how strange most readers find the arguments about giving a 'meaningful' presence to nonhuman things in academic research. This is why in Aramis he notes the student's dismay at Norbert's fanciful treatment of nonhumans as equivalent 'agents' in the world:

"My mentor's behaviour worried me a little. ... [H] e routinely thanked the automatic ticket machines at highway toll booths. He queried automatic tellers at banks about communication problems. He had long conversations with electric staplers.

(11) Latour attempts to counter criticism of homogenising Aramis as a singular coherent machinein-design by allowing the component bits and pieces to separate momentarily in a bit-player semicomic section (page 59). This is also a somewhat forced concession to his own argument about Aramis being a 'parliament of things', a central notion developed in his previous book (Latour, 1993a) to convey the image of the many diverse things of the world-human, nonhuman, and all shades in-between--sitting down to debate with one another. 
He noted the degree of politeness, laziness, violence, or nastiness of all the automatic door openers he came across, going so far as to tip them, which usually left them quite indifferent. He couldn't buckle up a seat belt without looking into its stiffness, flexibility, or looseness, undoing the springs in order to see where that morality of webbing and clasps could be coming from. One day he undertook a complete interview with a 'sleeping policemen'..." (pages 210-211).

More seriously, Latour directly confronts the objections which start to be made about 'anthropomorphising' the nonhuman things of the world, suggesting that in practice 'we' (academics and indeed and importantly everybody else) ${ }^{(12)}$ are routinely 'something-morphising' all of the constituents of the world in one way or another. The world cannot but be understood through such morphisings, so Latour declares, which means that raising objections to the process is absurd. By this token, to object to certain morphisings rather than to others is also absurd.

In a key passage for the whole book, Latour puts matters like this:

"Anthropomorphism purports to establish a list of the capabilities that define humans and that it can then project through metaphors onto other beings - whales, gorillas, robots, a Macintosh, an Aramis, chips or bugs. The word anthropomorphism always implies that such a projection remains inappropriate, as if it were clear to everyone that the actants on which feelings are projected were actually acting in terms of different competences. If we say that whales are 'touching', that a gorilla is 'macho', that robots are 'intelligent', that Macintosh computers are 'user-friendly', that Aramis has 'the right' to bump [etc]..., we are still supposing that 'in reality', of course, all this fauna remains brute and completely devoid of human feelings. Now, how could one describe what they are truly are, independently of any 'projection'? By using another list taken from a different repertory that is projected surreptitiously onto the actants? For example, technomorphisms: the whale is an 'automaton', a simple 'animal-machine'; the robot, too, is merely a simple machine. Man [sic] himself, after all, far from having feelings to project, is only a biochemical automaton.

We give the impression, then, not that there are two lists, one of human capabilities and one of mechanical competencies, but that legitimate reductionism has taken place of inappropriate anthropomorphism. Underneath projections of feeling, in this view, there is matter....

But what can be said of the following projection: 'The chips are bugged'? Here is a zoomorphism - bugs-projected onto a technology. Or this one: 'The gorilla is obeying a simple stimulus-response'? Here a technobiologism-the creation of neurologists - is reprojected on to an animal....

Let us [therefore] say that... there is never any projection onto real behaviour, the capabilities to be distributed form an open and potentially infinite list, and that is better to speak of $(x)$-morphism instead of becoming indignant when humans are treated as nonhumans or vice versa. The human form is as unknown to us as the nonhuman" (pages 225-227).

The impression is of an open plain across which are distributed all of the possible things of the world-humans, nonhumans, every shade in-between - all of which have many and varying forms and capabilities, and all of which are available to be deployed (by humans, but not necessarily by humans alone) to describe whatever things are

(12) Talking of 'we' and 'them' is precisely an example of the divide which Latour wishes to scramble, however, because it is a linguistic act of 'purification' carried out by social scientists to seal off their object of investigation (humans and their societies) from the proper domain of natural scientists (unconscious things and their nature). Yet 'we' (the human authors of this paper) still find ourselves doing precisely this all of the time. 
under consideration: to provide projections, '(x)-morphisms' allowing the envisaging and incorporation of other phenomenon less well-known. The further implication is that to do so, even to be highly anthropomorphic about nonhumans or technomorphic about humans, may be entirely appropriate: it may enable a suitable, malleable informative picturing of the forms, capabilities, and actions of the things being constituted.

Either way, particularly when discussing the Centre pour Experimentation Technicale (Centre for Technical Experimentation) (CET) stage where 'testing' of the Aramis technology occurred, Latour sets these ideas to work (but see also pages 60-62, where similar issues are aired). Here he directly confronts the technology composing Aramis. In the text Norbert begins to suspect that it was during the CEt stage that the project finally became 'fatally flawed' because the technology could not live up to the many complicated demands being put on it to pass its tests. This was not the same as suspecting, as did the student, that the project was fatally flawed from the outset because of sundry design faults present on the first drawing board. To cut a long scientitifiction short, as the story unfolds - and, curiously, as the student's engineering talents come increasingly into play (as he can understand the CET specifications whereas Norbert cannot, at which point it is Norbert who becomes riled by the loss of human 'mastery'!) - the picture hardens of Aramis as a collection of 'machines' (complex amalgams of engineering hardware and microprocessing software) which absolutely have to possess a great many qualities of agency usually only attributed to humans. The little cars have to be incredibly 'aware' of those in front of them; they have to be constantly 'monitoring' their speed, their precise location, and other detailed information which is constantly being relayed to them by the track equipment and beyond; and they have to be continually making 'decisions' about this information, 'assessing' its reliability (if it is suddenly considered unreliable they have to 'decide' to stop for reasons of 'security' or 'safety'). In a conversation between Norbert (N) and the student (s), buttressed by detailed documentary evidence (including diagrams) from the CET specifications, all of the above is explored at length:

"'[On first looking at the volumes of technological specifications] Crowds, more crowds.... A technology isn't one single character; it's a city, it's a collective, it's countless.... Look at all these people! [meaning, look at all of those gadgets, widgets, wirings]'” ( $\mathrm{N}$, page 227).

" “...the central command post [the PCC], which sees, understands, feels, decides, acts, orders, and manages the entire flow..." (s, page 230).

" "... in the mobile units, on the tracks, along the sectors, everything is done by nonhumans-but by tens of millions of them. And these nonhumans have names and capabilities; they're human parts. Now don't tell me that's not a fine piece of anthropomorphism" " $(\mathrm{N}$, page 230).

“" 'You need a minimum of democracy [echoes of Latour's 'parliament of things': see footnote (11)] - that is, delegation of tasks: the mobile units have to fend for themselves, in part'" (s, page 230).

“'I [momentarily talking as if one of the cars] go too fast-you can't send me enough information fast enough. You have to let me have an autonomous personality. I have to drive myself" " (s, page 231).

" 'No one will open the doors; it's too dangerous-someone nonhuman has to open them. No one will put on the brakes-someone nonhuman has to put them on and make sure they're working in synch with the car's speed, so they won't take hold too violently. No one will check to make sure the motor follows suit and idles-someone 
nonhuman will have to check it. No one will be there to say whether or not the onboard steering is on the correct side-someone nonhuman will have to say it. And all those someones-me, them, him, it, someone-have to calculate fast and have to be checked themselves by the UGE [a form of computer], which is the onboard conscience" " (s, page 232).

The point should be clear: Latour gradually secures the plausibility of phrases such as 'someone nonhuman', and fosters the powerful image of Aramis as this collection, this 'democracy', of nonhuman elements-objects, electrics, flows, bits of programmingwhich has the capacity to operate as if it were indeed a human, or a team of humans, as if it was a thinking-feeling-deciding entity, as if it were as alive as any human. It is appropriate to recall that these passages have been prefaced by a preemptory strike against anyone who might straightforwardly critique such an approach for its anthropomorphism: Latour is going to be anthropomorphic, openly, assertively, provocatively.

\section{Fat things, flat humans: emotional calculators}

What is also happening in Latour's x-morphising is that, just as the nonhumans are increasingly likened to humans, the humans involved are increasingly likened to nonhumans: or, more specifically, to machines (hence providing a technomorphism). The nonhumans are in effect 'levelled up' to the status of humans, and the humans are 'levelled down' to the status of nonhumans. Given the first manoeuvre, it is intriguing to find Aramis speaking, early in its biography, about nonhumans needing to be conceptualised more as humans:

" "I find your characters [the nonhuman things, the technological objects, as laid out in early specifications of the Aramis project] one-dimensional. They need to be animated: you have to make them move, give them depth and consistency. More than anything, they have to be autonomous; that's the whole secret. And instead they're so rigid! They'd pass for puppets. Look at that one: he has no personality, he doesn't know where he is, or what time it is, or where he's supposed to go, or whom he's supposed to meet. You have to tell him everything: "Go forward, go back, come closer, turn right, turn left, open the door, go ahead, watch out". Your characters are just sacks of potatoes. Give them a little breathing space, a little autonomy. Make them cars with minds of their own"' (page 55).

The CET specifications went ahead and envisaged the nonhumans in the system having exactly this autonomy, and these 'real' changes in Aramis's nonhuman components provide a model for the changing sociological approach towards nonhumans which Latour is proposing. Elsewhere Latour reflects briefly on the second manoeuvre noted above, that whereby humans are regarded more like nonhumans:

"Humans and nonhumans take on form by redistributing the competences and performances of the multitude of actors that they hold on to and that hold on to them. The form of Aramis's shock absorbers is a compromise between what Aramis can know-the speed and position of mobile units-and what humans can stand without discomfort-shocks of less than three metres per second. Let us note that here humans are being treated as objects that do or do not resist shocks, while nonhumans are granted knowledge, rights, a vote, and even refreshments" (page 225). Latour's moral, almost passionate, argument hence centres on the possibility of emancipating the nonhuman things that we humans have always already married and marshalled into our assemblies. It is blinkered social scientists whom he urges to extend their notion of agency beyond human activity, because other things impinging on the human world act, and act to assist in the shaping of that world. They have names, they solidify networks, they stabilise and constitute power relations; we delegate to them, we enlist them in our projects, we have expectations of them, we invest in 
them. In turn they act back on us, they carry their own expectations of humans, their own programmings of humans: how long can they allow us to get on and off the train? how quickly must an Aramis car come to a halt so as not to hurt its passengers?

The arguments reviewed above about $\mathrm{x}$-morphising are how Latour strives to evade the most obvious critiques of his work, ones which many will certainly want to direct at the anthropomorphism rampant in Aramis, and we too should acknowledge that we are not entirely convinced by his reasoning in this respect. Indeed, we wish to raise the problem of installing a great indifference between the countless things of the world, an indifference which arises when they end up being portrayed as potentially all the same: all cut from the same overall cloth of forms and capabilities, with specific links between particular things and particular associated forms and capabilities being disputed because to posit such links a priori goes against the principle of symmetrical explanation. Thus humans can be treated as if they are nonhuman things, ${ }^{(13)}$ and nonhuman things can be treated as if they are humans, and it all seems entirely 'reasonable' to do so. But can it really be that simple? Should we be concerned that there are still some things distinctively human, and perhaps too some things distinctively nonhuman, which get ignored in the process?

At one moment in the book Latour briefly reflects on how all things-people, mechanical machines, and electronic microprocessors-are alike because they all 'act' according to preset scripts: "they are programmes of action whose scriptors may delegate their realisation to electrons, or signs, or habits, or neurons" (page 223). This claim leads him to ask "is there no longer any difference between humans and nonhumans?" (page 223), and it is intriguing that, despite saying 'no' (that is, there is still a difference), his answer remains ambiguous because he immediately starts talking about machines being composites of 'spirit' and 'matter' [and being "souls through and through" (page 223)]. ${ }^{(14)}$ Is he ducking the issue? In the biography of someone nonhuman there are further claims about what comprises a subject, about what an 'I' or a 'me' might be, and it is Aramis who says:

"'I am the deep well into which they [the engineers, politicians, planners, and so on] are tossing their wishes, their hopes, and their curses. Blessed, cursed. Loved, hated. Indifferent, passionate. Plural, singular, masculine, feminine, neutral. I am waiting for them all to grant me being. What is a self? The intersection of all the sets of acts carried out in its name. But is that intersection full or empty?"' (page 201, emphasis added).

In reducing a self to "the intersection of acts carried out in its name" as a minimal definition, Latour clearly echoes the antihumanist stance of much poststructural

(13) It should be remembered that many postpositivist geographers and social scientists have devoted much time to criticising the tendency within conventional research to reduce humans to the status of mere things, objects or automatons seemingly devoid of anything that most people would recognise as distinctively human. Such a critique was the pivot of the attack which humanistic geographers mounted on previous incarnations of geography, most notably in Ley's (1980) spirited denouncing of a 'geography without man' and throughout virtually every page of a landmark text such as Ley and Samuels (1978). And, albeit in a different vocabulary and from different theoretical and political starting-points, feminist geographers have continued this battle against a vision of human beings (including both researchers and those being researched) which evacuates them of their subjectivity, their joys and sufferings, their passions and desires, in short their emotional agency (McDowell, 1992; Rose, 1993; 1997; WGSG, 1984; 1997). A certain irony perhaps attaches to the fact that, for all of these criticisms of 'thingification' in and beyond the discipline of human geography, we are now seriously contemplating a manoeuvre which quite explicitly 'thingifies' human beings (even if it does so in the name of 'humanising' things).

(14) Also we might address further his point about the 'quasi-object' or someone nonhuman as a hybrid of humans and nonhumans, as "a thing that possesses body and soul indissolubly" (page 213; and see especially the reasoning on pages $212-214$ ). 
thought, and perhaps also refrains a version of ethnomethodology which concentrates on observing actions and practices without necessarily positing authentic selves with discernible intentions behind them (Manning, 1992). Although we are excited by such a nonauthentic and nonintentional sense of self, it seems that we are left, as in ethnomethodology, with only observable-describable phenomena as empirical material, although, oddly, Latour speaks of (but infrequently from) intangible feelings such as love and passion. The 'flattened' humans populating Aramis, who merely act and sometimes think and talk, just do not appear to feel very much, especially besides the emotionally 'fattened out' nonhumans. ${ }^{(15)}$

Intriguingly, the only exception to this rather bloodless sense of action, emotion, and selfhood occurs in the biography of someone nonhuman, or Aramis itself, which at various moments mourns, pleads, and rages. As a consequence we sense, or perhaps we feel, that emotions are being squeezed out of the human actors in the Aramis network. Emotional agency seldom occurs: people (and often Aramis too) suffer emotions in the book, but these feelings are static, kept like an immobile background to the actions which really constitute change. A certain humorousness is the only emotional register which is added to the cool calculations of the engineers, politicians, and others, and humans are treated as beings who never resort to their emotions as 'clue' (Hochschild, 1983). Perhaps this emotional poverty is a legacy of Latour's previous work, which almost entirely left out the emotions felt by his laboratory scientists (Latour and Woolgar, 1979), and it is perhaps in turn a by-product of his materialistic semiotics: an orientation which allows him simultaneously to advance into the realm of hybrids while also stepping back into a more disengaged space (that is, semiotic theory) than that occupied by the non-superrefined sociologists who he attacks for creating a priori theories or for being too knowing (Lynch, 1993). ${ }^{16)}$ We then find ourselves wondering whether there is something needing to be said about a researcher who studies science and technology throughout his working life, and who evolves his own way of thinking that conjoins with laboratory forms of life and arguably becomes itself hybridised toward scientific modes of emotional denial. Does Latour distance himself from stuff that really does tend to offend the scientific or, here, the engineering sense of self?

The somewhat downgraded self or subject which acts like a machine, and perhaps more like a calculating or war machine than anything else, has a long lineage in Western thought (Machiavelli is cited on page 101). Latour, and Serres (1995) have

(15) If contrasted with many sociological depictions of humans, then Latour's are positively lively! Our key points here concern the deliberate and provocative $\mathrm{x}$-morphisings that Latour is also exploiting. (16) Looking back again to the significant engagement of SSK and STS with ethnomethodology, we find that in Garfinkel and Sack's (1970) founding document on studying practical action, indifference was set out as a key policy to avoid testing a priori models or theories on observed human action. Does such a statement also imply an emotional attitude towards humans of uninvolved description, or is it only about being indifferent to the professional claims of sociology to know what society and social rules are before, beyond, and above actual social actors? Garfinkel and Sacks (1970, page 346) put it thus: "[e]thnomethodological studies... are directed to seeking to describe members' accounts... while abstaining from all judgments of their adequacy, value, importance, necessity, practicality, success or consequentiality. ... [O]ur 'indifference' is to the whole of practical sociological reasoning, and that reasoning involves for us, in whatever form of development, with whatever error or adequacy, in whatever forms, inseparably and unavoidably, the mastery of natural language". It is also worth remembering that Latour draws on a semiotic legacy, particularly from the 'radical' end of de Saussure (1983), who first posited that all things are signs and are all, indeed, cut from the same cloth (on one side of which were signifiers and on the other side of which were signifieds). An enduring problem for semiotics is its atemporality, fixed as it always is in the signnetwork of the present. And ethnomethodologists would surely be critical of semiotics for its central project of mastering natural language with a professional scientistic metalanguage. 
expressed the philosophical hope that the knower can be pushed from the centre of the stage so that the world can be brought to life. What we wonder, having read Aramis, is whether the only actor capable of pushing (or tricking) the knower into the wings is Machiavelli's wily 'Prince', since only 'he' has the know-how to decentre the masterfully knowledgeable. Are we all to be treated as 'Princes', or is that just one partial understanding of human similarity and difference? Are we all merely calculators with calculative desires? Are we all reducible to what sometimes seems like a refined nonintentional variant of 'rational action theory'? It may be that, with an even closer reading of a text such as Aramis, we realise that a key measure of agency as conceptualised by Latour in this book [if not elsewhere (Hinchliffe, 1999)] resides quite straightforwardly in this power of 'calculation'. Paying attention to Latour's predilection for calculative beings ties in with his downplaying of emotion: people, for Latour, are basically 'cybernetic' not 'cyborg' beings (Haraway, 1991). They spend their days calculating tacitly, reflexively, jointly, responsively, the pros and cons of taking stands, making statements, pursuing courses of action, fighting measured wars by other means; and they are decidedly not emotional, passionate, irrational, tub-thumping, lustful, wasteful, 'real crappy human beings'. The latter aspects of being human, of being distinctively human even if not comprising exclusively human traits, appear to be almost wholly written out of Latour's vision.

These thoughts bring us squarely to the chief problem that we have with Aramis, and perhaps more generally with Latour (although we are hesitant about such a generalisation). Although in many ways we applaud the intellectually liberating manoeuvre of releasing nonhuman things from some interpretative netherworld, and although we are enthralled by imagining these nonhuman things as possessing agency, it may be that the plausibility of the manoeuvre depends upon an initial respecification of what agency entails. In other words, what is poured into the intersection marked 'agency' has possibly been overrefined: it has been filtered in subtle ways which render it, as it were, more attainable by nonhuman things, in the course of which humans have gradually been reenvisaged as more like nonhumans, notably machines. This development is clearly signalled in the 'what is a self' quote from Aramis cited above, wherein it is stated that the self is located at an intersection of threads and filaments which can only be examined in terms of being full or empty, and it is arguably only this minimal definition of the self that permits the subsequent radical blurring of humans and nonhumans. Because Latour has now recast agency in less exclusively and traditionally human terms, it becomes conceptually possible for nonhuman things to enter this particular conceptual space; and thus nonhumans become the bearers of agency and the human-nonhuman distinction disappears. Whereas many of us may now be willing to treat things as agents, we are more uncomfortable about treating them as speaking and writing agents, and are definitely uneasy about treating speaking and writing people 'merely' as things. ${ }^{(17)}$ Nonhumans must indeed be allowed an enlarged conceptual space in our inquiries, and we are happy to experiment with conceiving of nonhumans as possessing "knowledge, rights, a vote and even refreshments" (page 225), but in such an experiment we do not want to drain humans of many qualities such as the capacity for emotion that empirically, if not necessarily, tend to coexist with and in the distinctively different 'figure' that is the human. This is not to lapse into a simplistic humanism supposing there to be essential foundations of humanness, because, in keeping with much recent poststructural theory, we do regard 'being human' as a relational achievement across a number of registers (bodily, psychic, social). Nonetheless, we wish 
to keep in view the differences marking humans out as a different kind of thing in the wider order of things, particularly by remaining open to the exaltations and the terrors of an emotional life, of emotional agency, as experienced with a particular intensity-if not exclusively - by humans.

\section{All things being equal, we are indifferent: new spatial imaginaries?}

These thoughts now prompt us to conclude with some further speculations about what we might term the 'spatial imaginaries' permeating Aramis. On the one hand, there is an imaginary which pictures everything and anything (whatever its name) as a multiplicity of diverse forms and capabilities, a jumble of mixed-up entities, qualities, and origins, all bundled together in a knotty mass of entangled threads, bits, and pieces. Such a threaded and 'filamental' imaginary is figured in the quote about Ariadne's thread with which we began this review, and it is also mooted quite explicitly by Latour on a recent website entry (Latour, 1997; cited in Hinchliffe, 1999), and we will attend to this loose thread a little later. First we wish to reflect upon a second imaginary which is arguably at least as prominent, if downplayed, in Aramis, one that does imply more a flattened surface across which all of the things of the world are dispersed, still identifiable to some extent as individualised bits of humanity and nonhumanity, but not regarded as distinctively different in terms of their forms and capabilities. If this diagnosis is correct, then is there not a risk here of such an imaginary condoning a casual indifference, an indiscriminate sense of everything being everything else, with nothing raising itself at all distinctively above the plain?

The move to embrace flattened spatial imaginaries brings important gains, of course, and is seen by many as a key development in allowing a re-visioning of just what it is that scholars are striving to achieve. It is quite common now to hear calls to reject 'depth models' of social inquiry, predicated as they are on notions of levels, layers, foundations, hierarchies, and the like, and on a logic whereby certain domains of phenomena (for example, the economic, the psychohistorical) always tend to be prioritised over others. Curry (1992, page 97) critiques this sort of thinking in human geography, casting it as an 'architectonic impulse' which feeds "this desire to create an ordered, hierarchical system", and Darnton (1985) provides an equivalent challenging of the hierarchical-levels-type thinking shared by all manner of historians (whether Whigs, Marxists, Annalistes, - or whatever). One of us has argued along similar lines, proposing that Foucault's (1972) stress on 'spaces of dispersion' provides an alternative spatial imaginary in which the myriad things of the world are all portrayed as dispersed chaotically, unevenly, even fractiously across a plain, a surface, a flattened space (Philo, 1992). This approach deliberately proposes shifting from a three-dimensional imaginary to a two-dimensional one, and does so as an integral element of continuing struggles against the tyrannies of 'grand theory'. Yet, for all of the liberatory possibilities offered by countering the former imaginary with the latter, by resisting the tendencies toward hierarchical thought which valorise certain segments of reality while seeing others very much as trivial or derivative, new problems are arguably created by reaching a point where the flattening out process leads to an obscuring of differences between different definite and indefinite 'nounchunks' of reality (a/the factory, an/the airship, a/the child, a/the television programme, $\mathrm{a} /$ the dream). A conceptual development which began in the name of preserving difference, a purposeful move to 'flat spaces' of thought where differences cannot be reduced to mere deviations from a 'bell-curve norm', has perversely given rise to a danger that such difference becomes submerged in an homogenising indifference. Obscured in the process are not just the differences indexed by the overly familar human-machine binary, but also differences between kinds of humans and between kinds of machines. 
This consequence is certainly not specific to Latour's work, but there are perhaps signs of such a flattening leading to a form of indifference in both the general claims of ANT and the specific narrative of Aramis. We have already started to argue this point above when worrying about a levelling out of humans and nonhumans, and it has been suggested elsewhere that the symmetrical balancing of the differences between people and things generates a "scorched earth policy" (Lee and Brown, 1994, page 782; see also Hinchliffe, 1996) whereby the vertical structures raising parts of the world out of the plain of being are assimilated into the unstoppable and all-razing horizontal spread of actor-network collectives. Moreover, a case could be made that a significant part of Latour's spatial imaginary remains a geometric one, a variant of spatial science, which then references (for geographers at least) the vision of a surface crisscrossed by intersecting straight lines. The lower part of Latour's famous diagram in We Have Never Been Modern (Latour, 1993a, figure 1.1, page 11; see figure 3), where he portrays the "work of translation" that occurs as the countless human and nonhuman things of the world enter into hybrids and traverse networks, looks like a wiring diagram or a pile of coathangers, with bits of straightened metal wire laid down on a two-dimensional surface, joining and bisecting. It is also the case that scholars drawing upon Latour's work often speak about 'geometries' and 'topologies' (Hinchcliffe, 1996; 1999; Thornes, 1998; Whatmore, 1997; Whatmore and Thornes, 1998), thereby arriving at a spatial imaginary which potentially has all sorts of assumptions coded into it about the spatial order of coherent, traceable, and mappable networks (assumptions with which Latour and his 'followers' might well be uncomfortable). Just as humanistic geographers responded negatively to the spiky, rigid geometries of Hägerstrand's time-geographic diagrams (Buttimer described them as depicting a 'danse macabre' (Gregory, 1985, page 335; Rose, 1993, page 38)], could there not be a warrant for contemplating a similar line of objection to Latour's analytics? To return to Aramis, it is revealing that considerations of geometry are rarely absent: the student refers to Norbert's "variable-geometry reality" (page 78), and references are made to "the geometry of the actors" (page 88) and also to "the topology of technological projects" (page 108). In addition, the book is full of highly geometrical diagrams lifted from different planning

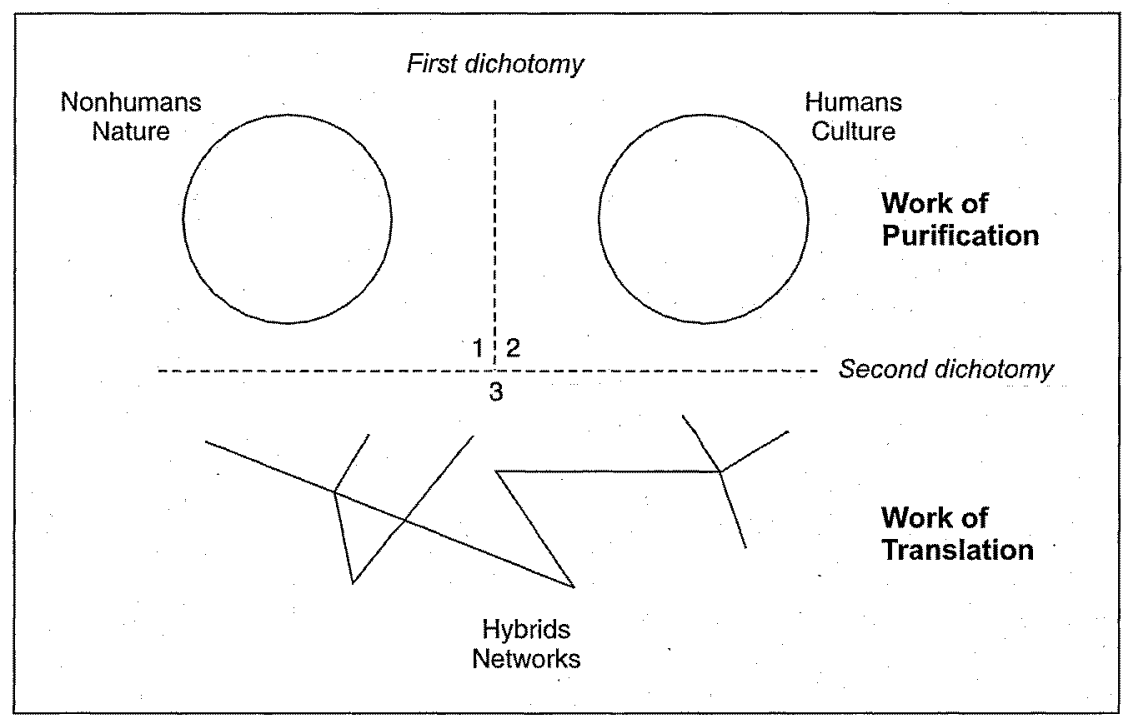

Figure 3. Latour's depiction of the differences between 'work of purification' and 'work of translation' (source: redrawn from Latour, 1993a, figure 1.1, page 11). 


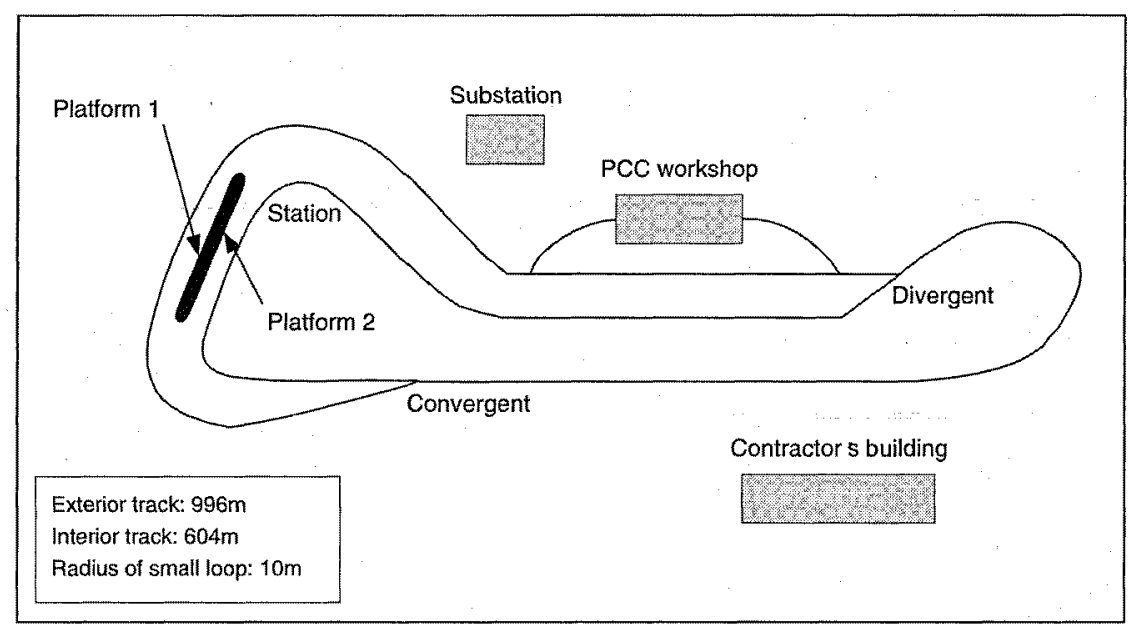

Figure 4. Just one of the plans from the documentation prepared at the Centre for Technical Experimentation stage (source: redrawn from Latour, 1996, figure 11, page 228).

phases in the near-life of Aramis (for an example, see figure 4), and, although we acknowledge that these diagrams are included as part of the evidence being sifted, their very presence 'rubs off' on how the text may be approached and its contents read. Unlike the grainy black-and-white photographs consigned to several pages clustered in the middle of the book, these diagrams are recurrent visual cues which may influence something of what readers take away from the book.

Considering matters in this fashion leads us to wonder about Latour's efforts in relation to other projects which, more or less deliberately, search for alternative spatial imaginaries. Rose's (1993) remarks about 'paradoxical spaces' through which to re-envisage feminist-geographical inquiries offer one such alternative, as too do her borrowings from Irigaray (1985) in seeking "to imagine a space which can articulate radical difference: a space of contradiction, reversals, paradoxes, a pleated and folded space" (Rose, 1995, page 416). Her search is for a less machinic, more humanbodily spatial imaginary than that offered by Latour, and it is also one which rejects flatness in favour of an uneven, contorted, and doubled-over sense of space. A further possibility is found in the meditations of Deleuze and Guattari (1984; 1988), some of whose ideas are quoted approvingly in Aramis (page 56) as another way of thinking about actor-networks (see also Lee and Brown, 1994; Murdoch, 1997b), and these writers undoubtedly furnish an abundance of alternative spatial imaginaries. Machinic lexicons certainly abound here, famously in the opening pages of Capitalism and Shizophrenia where the human world is described as nothing but an assemblage of machines: "it is machines-real ones, not figurative ones" (Deleuze and Guattari, 1984, page 1). Their texts proliferate (sometimes confusingly so) with spatial imaginaries, but perhaps best known is the figure of the 'rhizome' which "assumes very diverse forms, from ramified surface extension in all directions to concretion in bulbs and tubers" [(Deleuze and Guattari, 1988, page 7) and it is the figure of the rhizome that Latour reckons could be useful in representing his actor-networks]. Without a core or a centre, spreading out more-or-less horizontally through the surface layers of a soil mass, a rhizome is nonetheless much more three-dimensional than are the thin wires of the standard network depiction: it is earthy, it has body, it swells at points to produce bulbs and tubers breaking defiantly out of the horizontal, and as such it has rather more of the qualities favoured by Rose than the abstract geometries found in 
some, if not all, of Latour's corpus. ${ }^{(18)}$ Additional 'hooks' (as in a song) permeating the texts of Delezue and Guattari are possible orderings derived from fractal mathematics, the new physics and many other 'sciences', and Doel $(1996 ; 1999)$ brilliantly explains that the resulting assertions about both 'flatness' and 'returning to the surface' run parallel to another spatial imaginary which he refers to as their 'scrumpled geography'. Hence, for them, the surface is "composed of an infinity of interleaved intervals, joints, and folds (and ... and ... and), which fan out and snap shut to reveal the labyrinthine surface of a scrumpled geography of infinite variability" (Doel, 1996, page 437). Furthermore, "[t]his surface occupies-or still better, 'holds'-volume, just as the infolded surface of a sponge can be said to 'hold' depth" (page 437). This imaginary thereby escapes from a two-dimensional plain, not to reinstate a model of celibate spaces, levels, or blocks, but to retain the notion of difference: to accentuate in every pore the very different kinds of things existing in the world, as well as to emphasise the differing intensities of how 'stuff' is dispersed in, through, and across the spaces which are this world.

The flattened, single-layer imaginary that we have emphasised is probably not a depiction of Latour's work with which he would readily agree. As noted earlier, when offering one clarification of his take on ANT, he states quite explicitly that:

"[M]odern societies cannot be described without recognising them as having a

fibrous, thread-like, wiry, stringy, ropy, capillary character that is never captured

by the notions of levels, layers, territories, spheres, categories, structure, systems"

(Latour, 1997; cited in Hinchliffe, 1999).

This filamental imaginary holds fast if, and only if, we follow Latour's 'translation' of this definition onto a world achieved via associative social practices (actions which connect up actor-networks). Hinchliffe (1999) has unpicked some of Latour's neat stitching here by considering practices which are powerful because they are dis associative. Our unpicking is to tug at the a priori status of social practices themselves-the threadings-which appear to preexist the actors (the 'noun-chunks' who we mentioned earlier), and this is where Aramis is so instructive. Even if Latour might make claims otherwise, for all of his focus on actions, practices, and processes which are social orderings ('threading-verbs' not 'noun-chunks'), there can be little disputing that Aramis, the book, is full to bursting point with identifiable actors. To be sure, what can be considered as an actor has been broadened considerably, and an actor's status is no longer given but always requires work for its achievement, but these actors are still defiantly present: leaving threads behind, following threads, tying up loose threads, and changing threads. X-morphising in practice is about redistributing consistencies and competencies from and to actors (who do not necessarily have to be human and do not have any essential or nonrelational capabilities); or, in another terminology, it is about attaching a limited set of verbs to a collection of nouns. 'Aramis gains reality': which is why, in short, we have spent so much time contemplating the rich cast of social agents and how they are reconfigured throughout Aramis. The filamental imaginary runs the risk of obscuring these patches of Law and Mol's (1994) sociomaterial patchwork, because it only examines the stitching:

(18) One of the further dangers of the spatial imaginary associated with ANT is that actors as dissected and constituted by one network, such as Aramis, end up seeming 'monovalent' (personal communication, G Davies, 1998). Their multiple connections to other networks in their everyday lives are rendered irrelevant because they are not crossed by Ariadne's thread (page 152). If we as investigators allow our attention to be channelled wholly by the dimensions of the connective leading thread as we pass through the labyrinth of any research project, then we risk missing the other, often more complex, often more emotionally confusing, human maps of mattering (Gren, 1994; Grossberg, 1992) which tell a whole series of other stories: and sometimes even alternative stories about people and things. 
only felt (a chunk of material) could be that filamental. In the very title of the book, then, we have the irreducible couplet of an actor and a practice: "Aramis, or the love of technology".

Our last thought in this review is to wonder if other conceptual moves, perhaps other relations of people, things, and practices, might have arisen if the 'cuts' and plots taken to narrate specific actor-networks in Aramis had been different. For instance, what would have been lost if Aramis had lived to become an actually existing compromise, a passenger-ridden public transportation system? What would have happened had Latour then needed to consider not just the engineers and their tools involved in the production phase, but also myriad people and materials involved in the consumption, maintenance, and (in particular) repair of the system on a daily basis? ${ }^{(19)}$ Would his story have lost its entrancingly neat murder-mystery trope, unavoidably encountering a still more promiscuous jostling together of diverse actors running through and bumping up against Aramis, a plethora both of new humans (the commuters, the safety inspectors, the repair workers, etc) and of new nonhumans (animals on the track, tickets from the office, ploughs to clear the snow, etc)? Latour is far more interested in preassembly than postassembly. And what would have been the outcome if Aramis had not been a transport project but, say, a sophisticated new design for a whaling ship or a cat flap? Would Latour have contemplated a more messy distribution of knowledges, competences, and other attributions between the different actors germane to this actor-network, and more specifically would the intrusion of certain nonhuman animals - whales or cats - have problematised the picture by being just as plausible a locus of urges, aims, protests, anger, love, hunger, and distress as are the human characters? ${ }^{(20)}$ Without the specific actor-network of Aramis, perhaps the case would not have built up so exclusively around the terms of one binary - that of humans and machines-and would not have caused debate to polarise so starkly around questions of whether

(19) Latour's concerns do remain solidly with the work of those who are clearly fabricating technologies, whereas many other human geographers and social scientists are more concerned with what happens when a technological project gains reality. When Latour does focus his attention beyond the laboratory, test-track, the prototype, he then, perhaps perversely, prefers to emphasise the disappearance of things from our conscious consideration. In the case of Aramis the things are 'trains', but by extension he could be talking about telephones, automobiles, or photocopiers, and the basic claim is that when 'consuming' things, when they are in use, people end up taking them for granted and allow them to become 'black boxes' (see especially, pages 75-76). If Aramis had become a fully functional public transport system, then we would forget about its contingent and contested existence because it had become an obvious everyday actor-network, one whose 'black-boxed' functioning we would only become mildly interested in when it breaks down. The way in which things disappear once they 'live' amongst us borrows a central tenet of theories of ideology, which argue that ideology becomes effectively inscribed into the heart of our material culture, our language, our social relations because it has become taken-for-granted. As such, we no longer see the conflicting and cooperative interests inscribed in it, and are only minimally interested in how it works. Such a view of ideology has been challenged many times over, and in a similar vein we have to ask whether things really do become so taken-for-granted when they are no longer new to us. What about the trainspotters whose fascination for the microdetails of trains never ceases? What about consumer (mal)practices involving Latour's beloved high-tech and low-tech quasi-objects (Cockburn, 1994; Cockburn and Ormrod, 1993)? What about the emotional investments in rusty cars (Laurier, 1996)?

(20) It could also be that something akin to emotions might be attributed to whales and cats, hence reinforcing the point that an emotional life may not be solely the preserve of humans, even if in an empirical sense it is apparent that 'emotions' and 'people' do tend to go together. The possibility of attributing versions of intentionality and consciousness to nonhuman animals is explored in a fascinating manner, partially inspired by ANT, in Wilbert (1999). 
humans are like machines or vice versa? ${ }^{(21)}$ Would it also have been more difficult to end up with the inadvertent flattening out of humans and nonhumans that occurs at present, given that a fresh set of issues would arise concerning the conceptual status appropriate to nonhumans seemingly quite unlike those machines whose restricted possibilities for 'life' are projected onto humans at various points in Aramis? In the face of such complications - such a range of possible x-morphisings beyond the human-machine axis-our response is to continue borrowing parts of Aramis, while retaining a sense of their tendency, to paraphrase Latour, for wearing out in contact with other 'hard surfaces'.

\section{Coda from Eric and Chris: 'Neat book, Bruno'.}

Acknowledgements. Big thanks are due to Nigel Thrift for his encouragement and guidance as we have struggled to get this paper together. Equally big thanks are due to Gail Davies for sharing her perceptive thoughts, and to Steve Hinchliffe for his typical generosity and challenging suggestions. Further thanks are due to two anonymous referees, whose knowledge of ANT and framing of further questions to ask of the materials were invaluable. Thanks are also due to Les Hill for his photographic skills and to Yvonne Findlayson for redrawing figures 3 and 4. This paper was prepared as part of the theoretical work of an ESRC-funded project "Meet You At Junction 17: a socio-technical and spatial study of the mobile office" (ESRC R000222071), and we gratefully acknowledge this support. Dual authorship means that, in nearly all cases, the responsibility effect for the bad bits lies with the other author.

\section{References}

Ashmore M, 1989 The Reflexive Thesis: Wrighting the Sociology of Scientific Knowledge

(University of Chicago Press, Chicago, IL)

Barthes R, 1982 The Grain of the Voice (Cape, London)

Baudrillard J, 1987, "Forget Baudrillard: an interview with S Lotringer", in Forget Foucault

Ed. J Baudrillard (Columbia University Press, New York) pp 65-137

Bingham N, 1996, "Object-ions: from technological determinism towards geographies of relations" Environment and Planning D: Society and Space 14 635-657

Bloor D, 1976 Knowledge and Social Imagery (Routledge and Kegan Paul, London)

Callon M, Latour B, 1981, "Unscrewing the big leviathan", in Advances in Social Theory and Methodology: Towards an Integration of Micro- and Macro-sociologies Eds K Knorr-Cetina,

A Cicourel (Routledge, New York) pp 228-303

Cockburn C, 1994 Bringing Technology Home: Gender and Technology in a Changing Europe (Open University Press, Milton Keynes)

Cockburn C, Ormrod S, 1993 Gender and Technology in the Making (Sage, London)

Crang P, 1992, "The politics of polyphony: reconfigurations of geographical authority" Environment and Planning D: Society and Space $10527-549$

Curry M, 1992, "The architectonic impulse and the reconceptualisation of the concrete in contemporary geography", in Writing Worlds: Discourse, Text and Metaphor in the Representation of Landscape Eds T J Barnes, J S Duncan (Routledge, London) pp 97-117

Darnton M, 1985 The Great Cat Massacre and other Episodes in French Cultural History (Penguin Books, Harmondsworth, Middx)

Deleuze G, Guattari F, 1984 Anti-Oedipus: Capitalism and Schizophrenia, Volume 1 (Athlone Press, London)

Deleuze G, Guattari F, 1988 A Thousand Plateaus: Capitalism and Schizophrenia, Volume 2 (Athlone Press, London)

Demeritt D, 1996, "Social theory and the reconstruction of science and geography" Transactions of the Institute of British Geographers, New Series 21 484-503

de Saussure F, 1983 Course in General Linguistics (Duckworth, London)

(21) One referee spots that to an extent we have ourselves become captured in this all-pervasive binary from Aramis, and "are in danger of reproducing the same problem in [our] paper" by couching discussion principally in terms of humans and machines, rather than in terms of humans and a wealth of other nonmachinic nonhumans. 
Doel M, 1996, "A hundred thousand lines of flight: a machinic introduction to the nomad thought and scrumpled geography of Gilles Deleuze and Felix Guattari" Environment and Planning D: Society and Space $14421-439$

Doel M, 1999 Poststructuralist Geography: The Diabolical Art of Spatial Science (Edinburgh University Press, Edinburgh)

Eco U, 1988 The Name of the Rose translated by W Weaver (Minerva, London)

Foucault M, 1972 The Archaeology of Knowledge translated by A M Sheridan Smith (Tavistock Publications, London)

Garfinkel H, Sacks H, 1970, “On formal structures of practical actions”, in Theoretical Sociology Eds J C Mckinney, E A Finjakim (Appleton-Century-Crofts, New York) pp 337-360

Gregory D, 1985, "Suspended animation: the stasis of diffusion theory", in Social Relations and Spatial Structures (Macmillan, London) pp 296-336

Gregory D, 1994 Geographical Imaginations (Blackwell, Oxford)

Gren M, 1994, "Earth writing: exploring representation and social geography in-between meaning/ matter", publication series B, number 85, Department of Geography, University of Gothenburg, Gothenburg

Gross P, Levitt N, 1994 Higher Superstition (John Hopkins University Press, Baltimore, MD)

Grossberg L, 1992 We Gotta Get Out of This Place: Popular Music and Conservatism (Routledge, London)

Haraway D, 1988, "Situated knowledges: the science question in feminism and the privilege of partial perspective Feminist Studies 14 575-600

Haraway D, 1991 Simians, Cyborgs and Women: the Reinvention of Nature (Routledge, London)

Hinchliffe S, 1996, "Technology, power and space-the means and ends of geographies of technology" Environment and Planning D: Society and Space 14 659-682

Hinchliffe S, 1999, "Entangled humans: specifying powers and their spatialities", in Entanglements: Geographies of Domination/Resistance Eds J Sharp, P Routledge, C Philo, R Paddison (Routledge, London) forthcoming

Hochschild A, 1983 The Managed Heart: The Commercialisation of Human Feeling (University of California Press, Berkeley, CA)

Irigaray L, 1985 The Sex Which is Not One translated by C Porter (Cornell University Press, Ithaca, NY)

Latour B, 1987 Science in Action: How to Follow Engineers and Scientists Through Society (Open University Press, Milton Keynes)

Latour B, 1988, "The politics of explanation", in Knowledge and Reflexivity: New Frontiers in the Sociology of Knowledge Ed. S Woolgar (Sage, London) pp 155-176

Latour B, 1991, "Technology is society made durable", in A Sociology of Monsters: Essays on Power, Technology and Domination Ed. J Law (Routledge, London) pp 103-131

Latour B, 1992, "Where are the missing masses? The sociology of a few mundane artifacts", in Shaping Technology/Building Society Eds W Bijker, J Law (MIT Press, London) pp 225-258

Latour B, 1993a We Have Never Been Modern (Harvester Wheatsheaf, Hemel Hempstead, Herts)

Latour B, 1993b, "Ethnography of a high tech case: about Aramis", in Technological Choices: Transformations in Material Cultures Since the Neolithic Ed. P Lemonnier (Routledge, London) pp 372-398

Latour B, 1996 Aramis, or the Love of Technology translated by C Porter (Harvard University Press, Cambridge, MA)

Latour B, 1997, "On actor-network theory: a few clarifications”, working paper, Centre for Social Theory and Technology, University of Keele, Keele, Staffs; available at http://www.keele.ac.uk/ depts/stt/staff/j/pubs-j|2.htm

Latour B, Woolgar S, 1979 Laboratory Life: The Social Construction of Scientific Facts (Sage, London)

Laurier E, 1996 City of Glas/z unpublished PhD thesis, Department of Geography, University of Wales, Lampeter, Ceredigion

Laurier E, 1999, "Geographies of talk: 'Max left a message'” Area 30 35-48

Laurier E, Philo C, 1999, "Meet you at Junction 17: a socio-technical and spatial study of the mobile office", Economic and Social Research Council final report on award R000222071; copy available from the authors

Law J (Ed.), 1991 A Sociology of Monsters: Essays on Power, Technology and Domination (Routledge, London)

Law J, 1994 Organising Modernity (Blackwell, Oxford)

Lee N, Brown S, 1994, “Otherness and the actor-network: the undiscovered continent" American Behavioural Scientist $37772-790$ 
Ley D, 1980, "Geography without man: a humanistic critique”, RP24, Department of Geography, University of Oxford, Oxford

Ley D, Samuels M S (Eds), 1978 Humanistic Geography: Prospects and Problems (Croom Helm, London)

Lynch-M, 1993 Scientific Practice and-Ordinary Action: Ethnomethodology and Social Studies of Science (Cambridge University Press, Cambridge)

McDowell L, 1992, "Doing gender: feminism, feminists and research methods in human geography" Transactions of the Institute of British Geographers, New Series $17399-416$

Manning P, 1992 Erving Goffman and Modern Sociology (Polity Press, Cambridge)

Mol A, Law J, 1994, "Regions, networks and fluids: anaemia and social topology" Social Studies of Science 24 641-672

Murdoch J, 1995, 'Actor-networks and the evolution of economic forms: combining description in theories of regulation, flexible specialisation and networks" Environment and Planning A 27 $731-757$

Murdoch J, 1997a, "Towards a geography of heterogeneous associations" Progress in Human Geography $21321-337$

Murdoch J, 1997b, "Inhuman/nonhuman/human actor-network theory and the prospects for a nondualistic and symmetrical perspective on nature and society" Environment and Planning D: Society and Space $15731-756$

Pfohl S, 1992 Death at the Parasite Café: Social Science Fictions and the Postmodern (Macmillan, London)

Philo C, 1992, "Foucault's geography" Environment and Planning D: Society and Space $10137-161$

Philo C, 1995, "Animals, geography, and the city: notes on inclusions and exclusions" Environment and Planning D: Society and Space 13 655-681

Philo C, Wolch J, 1998, "Through the geographical looking glass: space, place and society-animal relations" Society and Animals $6103-118$

Pickering A (Ed.), 1992 Science as Practice and Culture (University of Chicago Press, Chicago, IL)

Rose G, 1993 Feminism and Geography: The Limits of Geographical Knowledge (Polity Press, Cambridge)

Rose G, 1995, "Tradition and paternity: same difference" Transactions of the Institute of British Geographers, New Series 20 414-416

Rose G, 1997, "Situating knowledges: positionality, reflexivities and other tactics" Progress in Human Geography 21 305-320

Serres M, 1995 Conversations on Science, Culture and Time (University of Michigan Press, Ann Arbor, MI)

Thornes L, 1998, "Kangaroos: the non-issue" Society and Animals $6167-182$

Thrist N, 1996 Spatial Formations (Sage, London)

Whatmore S, 1997, "Dissecting the autonomous self-hybrid cartographies for a relational ethics" Environment and Planning D: Society and Space 15 37-54

Whatmore S, Thornes L, 1998, "Wild(er)ness: reconfiguring the geographies of wildlife" Transactions of the Institute of British Geographers 24 435-454

Wilbert C, 1999, "Anti-this - against-that: resistances along a human/nonhuman axis", in Entanglements: Geographies of Power/Resistance Eds J Sharp, P Routledge, C Philo, R Paddison (Routledge, London) forthcoming

Woolgar S (Ed.), 1988 Knowledge and Reflexivity: New Frontiers in the Sociology of Scientific Knowledge (Sage, London)

Woolgar S, 1991, "The turn to technology in social studies of science" Science, Technology and Human Values $2020-50$

WGSG, 1984 Geography and Gender: An Introduction to Feminist Geography Women and Geography Study Group of the IBG (Hutchinson, London)

WGSG, 1997 Feminist Geographies: Explorations in Diversity and Difference Women and Geography Study Group of the RGS/IBG (Addison Wesley Longman, Harlow, Essex) 